\title{
China \& the UN Declaration on the Rights of Indigenous Peoples: The Tibetan Case
}

Michael C. Davis, May 272014
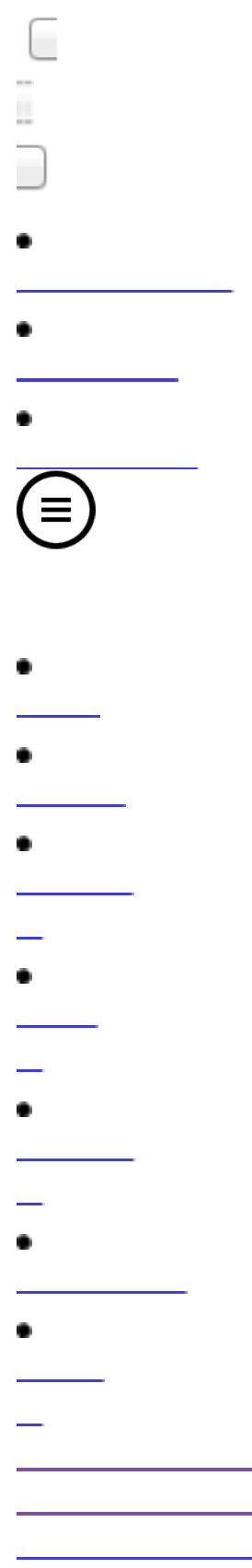
http://www.e-ir.info/2014/05/27/china-the-un-declaration-on-the-rights-of-indigenouspeoples-the-tibetan-case/ Page 1 of 9

China \& the UN Declaration on the Rights of Indigenous Peoples: The Tibetan Case 1/1/15 4:49 PM

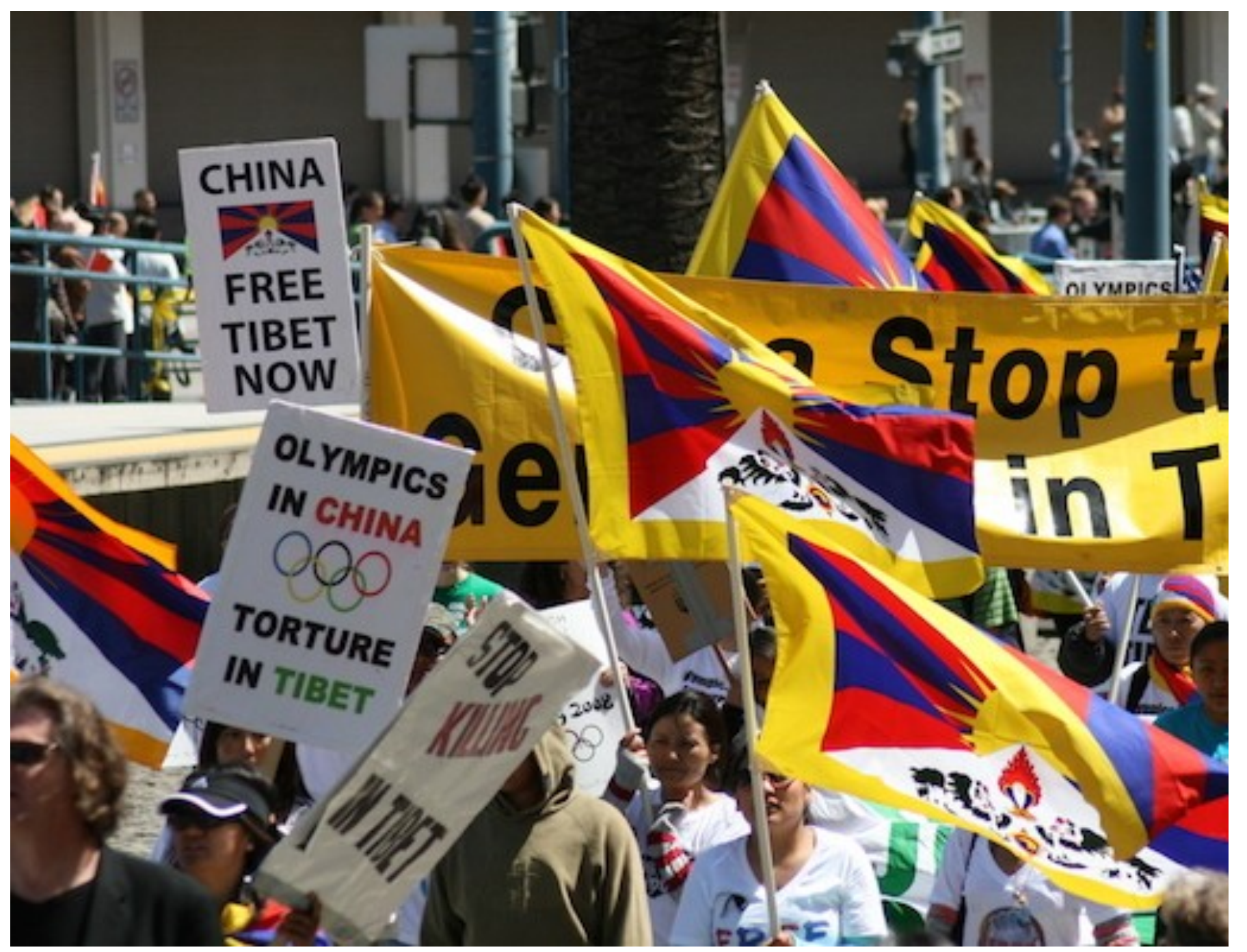

Image by Michael Sheehan

This article is an excerpt from E-IR's free-to-download Edited Collection, Restoring Indigenous Self Determination. View all of E-IR's Publications here.

Using sovereignty as a shield, the People's Republic of China (PRC) has generally sought a pass in regard to enforcing international human rights compliance. Though it has signed numerous human rights treaties, its state-centered approach has 
sought to avoid all efforts at enforcement. This avoidance has nowhere been more absolute than its disavowal of any obligations regarding indigenous peoples' rights. The PRC actually voted in support of the 2007 United Nations Declaration on the Rights of Indigenous Peoples (UNDRIP) (UN General Assembly 2008). It then promptly disavowed any obligation under the declaration, proclaiming there were no indigenous peoples in China. It proclaimed 5,000 years of unity and harmony with its 55 designated national minorities living in peace on their own land. Though a bloody history and recent protests by the most prominent of these minorities - Tibetans, Uyghurs, and Mongols - would tend to belie such assertion, the international community has rarely challenged this claim.

PRC protestations aside, a reasonable case can be made that China does have indigenous peoples among the peoples it has formally identified as national minorities. Narrowing the focus to Tibet, this paper will assess China's claims of exception from indigenous obligations and evaluate, on a general level, compliance with relevant international standards. This analysis appreciates that a mere UN declaration is usually not considered hard international law, though it may, under some circumstances, reflect customary international law. At a minimum, the UNDRIP, which sought to reflect existing customary international law, may be judged to offer a compelling guideline that China itself effectively embraced with its supporting vote.

\section{The UN Declaration and China}

While the UNDRIP does not offer a specific definition of "indigenous peoples," it does specify that they exist throughout the world.[1] A 1986 UN study offered a definition seeking to include "communities... which, having a historical continuity with preinvasion and pre-colonial societies that developed on their territories, consider themselves distinct from other sectors of the societies now prevailing" (UN Economic 
$\overline{\mathrm{http}}$ //www.e-ir.info/2014/05/27/china-the-un-declaration-on-the-rights-of-indigenouspeoples-the-tibetan-case/ Page 2 of 9

China \& the UN Declaration on the Rights of Indigenous Peoples: The Tibetan Case 1/1/15 4:49 PM

and Social Council 1986). The emphasis on distinctive selfidentification clearly applies in this case. Even by China's own account, in its 2009 White Paper on Tibet, the Tibetan people are clearly recognized as having a distinctive culture, language, and history, and constitute the vast majority in Tibetan areas (People's Republic of China 2009). The invasion mentioned in the definition is likewise evident in the 1950-51 Chinese invasion of Tibet, which resulted in the Seventeen Point Agreement[2] with the Dalai Lama, promising Tibetans the right to continue under their traditional governance in exchange for acceptance of Chinese sovereignty.[3] That this agreement was clearly an unequal agreement that the Dalai Lama could hardly refuse is another feature it shares with similar indigenous agreements around the world.

The UNDRIP identifies a number of standards that could appropriately be applied to assess prevailing conditions in Tibet. Its preliminary articles emphasize demilitarization of indigenous lands; the right of indigenous people to freely determine their relationship with states; that treaties, agreements, and constructive arrangements with states are matters of international concern; "the fundamental importance of the right of self-determination of all peoples, by virtue of which they freely determine their political status and freely pursue their economic, social and cultural development"; and that the right to exercise self- determination in conformity with international law shall not be denied. That Tibet is heavily militarized, and that the Tibetan people have never been allowed to make a free choice in determining their association with PRC, is widely appreciated. Efforts by the exiled Tibetan 
leadership to negotiate agreement concerning these issues have been consistently rebuffed. International concern over these matters has been the subject of numerous non-governmental organization, national, and international reports.

The UN Declaration, in its main text, guarantees indigenous peoples the right of self-determination; the right to autonomy or self-government in matters relating to their internal and local affairs; the right to manifest, practice, develop, and teach their spiritual and religious traditions, customs, and ceremonies, including private access to their religious and cultural sites and control of their ceremonial objects; the right to participate in decision-making in matters which would affect their rights, through representatives chosen by themselves in accordance with their own procedures; the right to be consulted and given prior consent through their own representative institutions before implementing state legislative and administrative measures; and the right to recognition, observance, and enforcement of treaties, agreements, and other constructive arrangements.[4] At the same time, they are guaranteed the rights protected by various human rights treaties and covenants. China's nationwide imposition of top-down authoritarian rule, its dismissive responses to Tibetan efforts at negotiation, and its weak general protection of basic human rights clearly fail to meet these standards. A closer look in the following section shows just how far China has strayed from these standards and even its own earlier commitments reflected in the Seventeen Point Agreement.

\section{Tibetan "Autonomy" Under PRC Rule}

The Seventeen Point Agreement that China imposed on Tibet when it occupied the country in 1950-51 actually came closer than any subsequent policies to the standards of the UNDRIP. The agreement acknowledged Tibet's special status, promised autonomy, and upheld Tibet's traditional system of self-rule. Chinese officials in the revolutionary zeal of the 1950s, however, 
showed little regard for these commitments, as they sought to impose "democratic reform" under Chinese Communist Party (CCP) rule, which they imagined Tibetans would quickly embrace. Chaffing under such an invasive approach, popular rebellion ensued and the Dalai Lama fled to India in March of 1959. There he established a government in exile that persists to the present (Dalai Lama 1991). If the Dalai Lama had stayed in Tibet, it seems likely that the Tibetan people and the world at large would have ultimately been deprived of one of the world's leading spiritual leaders.[5]

After the Dalai Lama fled into exile, PRC leaders abandoned their commitments under the Seventeen Point Agreement and established the Tibetan Autonomous Region (TAR) where, under the current Law on National Regional Autonomy (LRNA), central control clearly outweighs any notion of autonomy (China 1984 [2001]). About half of the contiguous traditional Tibetan areas have been distributed across 12 lesser

http://www.e-ir.info/2014/05/27/china-the-un-declaration-on-the-rights-of-indigenouspeoples-the-tibetan-case/ Page 3 of 9

China \& the UN Declaration on the Rights of Indigenous Peoples: The Tibetan Case 1/1/15 4:49 PM

autonomous areas in adjoining provinces, in what looks to Tibetans like a divide-and-conquer strategy. The large military presence, especially in the TAR, suggests the PRC views Tibet more in terms of national security than indigenous rights. The LRNA applies to all 55 designated national minorities, but the heavy- handed direct control practiced under its provisions seems targeted mostly at Tibet and the Uyghur areas in neighboring Xinjiang. A suspicious mind may wonder whether the generous designation of so many national minorities aims to water down such quasi-indigenous status.

The 1982 PRC Constitution, passed after the Cultural Revolution 
during China's liberalizing phase, appears to offer local autonomy. Article 4 provides that "Regional autonomy is practiced in areas where people of minority nationalities live in concentrated communities" (China 1982). As is replicated in the LRNA, such autonomy includes the power to enact "regulations on the exercise of autonomy (zizhi tiaoli) and other separate regulations (danxing tiaoli) in light of the political, economic and cultural characteristics." (China 1982;1984).[6] "Regulations on the exercise of autonomy" are effectively a sub-constitution or basic law, and one such law would be enacted in each region. A difficulty has been the requirement of higher approval for all such laws enacted in autonomous regions. Such approval must typically come from the next higher level of government: for autonomous regions, the central government, and for autonomous prefectures and counties, the provincial government. None of the PRC's five autonomous regions - being Tibet, Xinjiang, Inner Mongolia, Guangxi, and Ningxia - have received approval for such basic regulation on the exercise of autonomy. The attempt to enact a basic regulation in the TAR went through 15 drafts and was eventually abandoned without being submitted to the State Council (Ghai and Woodman 2009). Autonomous prefectures and counties have received approval from provincial governments for basic autonomy laws, but these simply track the LRNA content, showing little evidence of local autonomy. Autonomous regions and other areas have enacted many "separate regulations."[7] A third category would be ordinary laws unrelated to autonomy, which do not require such higher approval.

The picture that emerges is one of strict central control. Beyond the official approval required for enactment of autonomous laws, this control is most substantially exercised through CCP oversight at all levels. CCP committees are required to approve draft legislation at every step in the legislative process (Xia 2009). Other factors that facilitate this careful control of political choice in such minority autonomous regions include the replication of national political 
structures, such as people's congresses and CCP oversight at all levels of autonomous government; the reality that Chinese cadres always hold the top CCP position in the regions; and, finally, a communist ideology that claims Chinese "liberation" of the area and effectively denies the indigenous reality of such regions.

The outcome has been decades of Chinese domination and repression in Tibetan regions. During periods of national political chaos and repression, such as the Cultural Revolution, the level of destruction has been palpable, breeding high levels of Tibetan resentment. While recent years have seen Chinese policy encourage economic development, these moves have not been met with the hoped-for Tibetan gratitude. Tibetans have tended to see these policies as self-serving efforts to facilitate resource extraction, open up Chinese migration into Tibetan areas, and repress opposition - all favoring Chinese interests. Repressive efforts that have included close monitoring and "reeducation" in Tibetan monasteries, and a strong presence of security forces have bred even more resentment. Tibetan opposition has been manifest in various protests and even riots, and, most recently, in over 120 self-immolations (Davis 2012). Any pretext of carrying out the original promise of the Seventeen Point Agreement, or even current national minority laws, has largely evaporated. Current policies fall far short of the promise of the UNDRIP.

\section{The Tibetan Memorandum and the Failure of Negotiation}

The demonstrations and riots in 2008 came at a particularly inopportune time for the PRC, as it prepared to host the 2008 Olympics. Efforts at damage control led to three critical meetings straddling the Beijing Olympics in May, July, and October of 2008. For years the Dalai Lama had advocated what he labeled a "middle way" approach to achieving genuine autonomy for Tibet, an approach he urged could fit under the

http://www.e-ir.info/2014/05/27/china-the-un-declaration-on-the-rights-of-indigenouspeoples-the-tibetan-case/ Page 4 of 9 
China \& the UN Declaration on the Rights of Indigenous Peoples: The Tibetan Case 1/1/15 4:49 PM

PRC Constitution (Central Tibetan Administration 2006). With the Beijing Olympics approaching, in the July 2008 meeting, Chinese officials asked the Dalai Lama's representatives to submit a memorandum indicating how their middle way approach would fit under the PRC Constitution. The Tibetan Memorandum on Genuine Autonomy for the Tibetan People was submitted to Chinese officials at the October 2008 meeting, which followed closely on the heels of the Beijing Olympics (Central Tibetan Administration 2008).[8]

The Tibetan memorandum outlined areas of hoped-for autonomy in eleven policy areas that largely tracked the autonomy areas identified in the PRC Constitution: language, culture, religion, education, environmental protection, utilization of natural resources, economic development and trade, public health, internal public security, population migration, and cultural, educational, and religious exchanges with other countries. In seeking local control over immigration and external relations in the commercial and cultural areas, the memorandum appeared to track the somewhat more robust autonomy afforded to Hong Kong and Macau under Article 31 of the PRC Constitution (China 1982). The memorandum also sought to avoid the central government approval process required under existing national minority laws. Finally, the memorandum sought to unify all contiguous Tibetan autonomous areas into one. All of these areas easily track the guidelines in the UNDRIP.

The official Chinese response to Tibetan overtures and the Memorandum clearly signaled the PRC's dismissal of the UNDRIP requirement of negotiating with freely chosen representatives of indigenous peoples. PRC officials promptly downgraded the discussions, indicating Sino-Tibetan "contacts and dialogues were about the Dalai Lama's personal future, and not so- 
called 'China-Tibet negotiation' or 'dialogue between Han and Tibetan people'” (Xinhua, 6 July 2008). The PRC's official aim was clearly damage control, as it insisted on three "stops" to "stop activities aimed at splitting China, stop plotting and inciting violence and stop disrupting and sabotaging the Beijing Olympic Games" (Xinhua, 6 July 2008). This was later refined to "four nonsupports": "not to support activities to disturb the upcoming Beijing Olympic Games, not to support plots to fan violent criminal activities, not to support and concretely curb the violent terrorist activities of the 'Tibetan Youth Congress' and not to support any argument and activity to seek 'Tibet independence' and split the region from the country" (Xinhua, 6 July 2008). Chinese officials dismissively challenged the Dalai Lama's credentials to represent the Tibetan people, insisting that he must speak to the central government as a "common person" (IndoAsian News Service 15 July 2008). They launched vociferous personal attacks, labeling the Dalai Lama a "wolf in monk's robes" (Davis 2008).

Responding directly to the Tibetan Memorandum, a State Council Address likened the Tibetan notion of "genuine autonomy" to the "high degree of autonomy" allowed Hong Kong.[9] The Tibetans were accused of seeking "half-independence" and "covert independence," though no explanation is given why the same language applied to Hong Kong means only autonomy. The State Council Address further accuses the exiled Tibetans of "colluding with such dregs as 'democracy activists', 'falunkun (Falungong) elements' and 'Eastern Turkistan terrorists." The Tibetan Memorandum's proposal to gain control over immigration into Tibet is likened to "ethnic cleansing." The State Council Address declared, "We never discussed the so-called 'Tibet issue' and will 'never make a concession."' This language suggests the most extreme rejection of basic indigenous rights and associated autonomy for Tibetans. 


\section{Conclusion}

Chinese officials responsible for Tibet policy, primarily in the PRC United Front Works Department, appear to see Tibet primarily as a security problem. Their views seem similar to historical colonialist policies, including a sense that they are bringing a superior culture and economic development to the region. One frequently hears Chinese expressions of concern about Tibetan ingratitude for generous Chinese investment in Tibetan areas. When this view is combined with Chinese claims of historical title to Tibet, Chinese outrage at the Tibetan challenge has left little room for compromise. The Dalai Lama, while offering compromise, has refused to bow to Chinese interpretations of Sino-Tibetan history. Chinese

http://www.e-ir.info/2014/05/27/china-the-un-declaration-on-the-rights-of-indigenouspeoples-the-tibetan-case/ Page 5 of 9

China \& the UN Declaration on the Rights of Indigenous Peoples: The Tibetan Case 1/1/15 4:49 PM

officials may conclude that such refusal will deprive any settlement of full legitimacy.

Confronted with the difficult reality of Chinese occupation, the Dalai Lama, as reflected in the Tibetan Memorandum, has offered to accept "genuine autonomy" under Chinese sovereignty. Chinese distrust of his representations, in the Memorandum and elsewhere, has left an impasse. The Dalai Lama has persisted in his efforts to reach compromise under his middle way approach, though skepticism about any breakthrough abounds. With his reservoir of support in the Tibetan community, Tibetans in exile have generally supported the Dalai Lama's efforts, though skepticism is growing within the Tibetan exile community. There is very little trust that the Chinese have any interest in compromise, the perception being that they are just biding their time, awaiting a post-Dalai Lama period when they expect the Tibetan exile movement to collapse. 
The question to be asked is whether the Chinese are squandering the opportunity offered by the Dalai Lama, personally, and the Tibetan Memorandum, as a negotiating document, to reach a compromise. Should they take advantage of the Dalai Lama's ability to garner support in the Tibetan community for any agreement reached in line with international standards and the Tibetan Memorandum? Until their policies begin to measure up to international standards, such as reflected in the UNDRIP, their claims regarding Tibet and other critical minority areas will continue to meet global skepticism, even while their power has garnered formal recognition of their sovereignty over Tibet. Given the visibility of this issue in nearly every Chinese foreign policy outing, the price paid for these poorly conceived policies surely stretches beyond Tibet to skepticism in general about China's rise. Until the PRC acknowledges its international obligations, the deplorable human rights situation in Tibet seems destined to continue, as will a festering political sore covering nearly onequarter of contemporary Chinese territory.

\section{Notes}

[1] At the time of the Declaration there was thought to be over 370 million indigenous people worldwide (International Herald Tribune 13 September 2007).

[2] The full title is the "Agreement of the Central People's Government and the Local Government of Tibet on Measures for the Peaceful Liberation of Tibet," which was signed on 23 May 1951.

[3] The title of the agreement appears to suggest that China was just reclaiming an historical possession, but Tibetan resistance and numerous scholarly historical assessments call this into question (see Smith, Jr. 1996; Crossley 1999; Sperling 2004). In the present worldview, one might expect the efforts of one nationality to claim ownership over another nationality with its own distinctive culture 
and identity to be viewed with skepticism (see Davis 2012). [4] See UNDRIP Articles 3, 4, 12, 18, and 19 (UN General Assembly 2008).

[5] The 10th Panchen Lama, the second highest Tibetan spiritual leader, who stayed behind to support Chinese rule wound up spending nearly two decades in prison or under house arrest and eventually died at age 51 . His successor designated by the Dalai Lama disappeared as a child and has not reappeared since.

[6] Such provision is repeated in Article 66 of the Legislative Law of China.

[7] Separate regulations are made by autonomous legislative bodies on specific topics, such as language, marriage, family planning, and so on.

[8] After Beijing responded to the Memorandum, the exiled government published a separate response note (see Central Tibetan Administration 2010).

http://www.e-ir.info/2014/05/27/china-the-un-declaration-on-the-rights-of-indigenouspeoples-the-tibetan-case/ Page 6 of 9

China \& the UN Declaration on the Rights of Indigenous Peoples: The Tibetan Case 1/1/15 4:49 PM

[9] Address at the Press Conference by the State Council Office, Beijing, 10 November 2008 (address given by Mr. Zhu Weiqun, Executive Vice-Minister of the United Front Work Department of the CPC Central Committee). The United Front Work Department is responsible for national minority affairs.

\section{References}

Central Tibetan Administration. (2006) The Middle-Way Approach: A Framework for Resolving the Issue of Tibet. Dharamsala, India: Department of Information and International 


\section{Relations.}

Central Tibetan Administration. (2008) Memorandum on Geniune Autonomy for the Tibetan people. Available at:

http://tibet.net/important-issues/sino-tibetandialogue/memorandum-on-geniune-autonomy- for-the-tibetanpeople/ (Accessed 7 January 2014).

Central Tibetan Administration. (2010) Note on the Memorandum on Genuine Autonomy for the Tibetan People. Available at:

http://tibet.net/important-issues/sino-tibetan-dialogue/note-on-thememorandum-on- genuine-autonomy-for-the-tibetan-people/ (Accessed 7 January 2014).

China. Fifth National People's Congress. (1982) Constitution of the People's Republic of China. Available at:

http://english.peopledaily.com.cn/constitution/constitution.html (Accessed 7 January 2014).

China. Sixth National People's Congress (1984 [revised in 2001]) Law of the People's Republic of China on Regional National Autonomy. Available at:

http://www.china.org.cn/english/government/207138.htm (Accessed 7 January 2014).

Crossley, P. (1999) A Translucent Mirror: History and Identity in Qing Imperial Ideology. Berkeley: University of California Press.

Dalai Lama. (1991) Freedom in Exile: The Autobiography of the Dalai Lama. New York: HarperCollins Publishers.

Davis, M.C. (2008) "For Talks to Succeed, China Must Admit to a Tibet Problem." YaleGlobal Online, May 16. Available at:

http://yaleglobal.yale.edu/content/talks-succeed-china-must-admittibet-problem (Accessed 7 January 2014).

Davis, M.C. (2012) “Tibet and China’s 'National Minority’ 
Policies." Orbis, Summer 2012: 429-46.Ghai, Y. and Woodman, S. (2009) "Unused Power: Contestation Over Autonomy Legislation in the PRC."

Pacific Affairs, 82(1): 29-46.

People's Republic of China. Information Office of the State Council. (2009) Fifty Years of Democratic Reform in Tibet. White Paper. Available at: http://www .chinadaily.com.cn/china/200903/02/content_7527376.htm (Accessed 7 January 2014).

Smith, W.W., Jr. (1996) Tibetan Nation: A History of Tibetan Nationalism and Sino-Tibetan Relations. Boulder, Colorado: Westview.

Sperling, E. (2004) The Tibetan-China Conflict: History and Polemics. Washington, DC: East-West Center W ashington.

UN Economic and Social Council. Sub-Commission on the Prevention of Discrimination and Protection of Minorities. (1986) Study of the Problem of Discrimination Against Indigenous Peoples by Special Rapporteur José Martinez Cobo. UN Doc. E/CN.4/Sub.2/1986/21/Add.8.

http://www.e-ir.info/2014/05/27/china-the-un-declaration-on-the-rights-of-indigenouspeoples-the-tibetan-case/ Page 7 of 9

China \& the UN Declaration on the Rights of Indigenous Peoples: The Tibetan Case 1/1/15 4:49 PM

UN General Assembly. (2008) United Nations Declaration on the Rights of Indigenous Peoples resolution / adopted by the General 
Assembly. 2 October 2007, UN. Doc. A/RES/61/295.

Xia, C. (2009) “Autonomous Legislative Power in Regional Ethnic Autonomy of the People's Republic of China." In: Oliveira, J. and Cardinal P. eds. One Country, Two Systems, Three Legal Orders: Perspectives of Evolution. Berlin and Heidelberg: Springer-Verlag.

About The Author (Michael C. Davis):

Michael C. Davis, a professor in the Law Faculty at the University of Hong Kong, has held visiting chairs in human rights at Northwestern University Law School (2005-06) and Notre Dame Law School (2004-05), as well as the Schell Senior Human Rights Fellowship at the Yale Law School (1994-95). His publications include Constitutional Confrontation in Hong Kong (1990), Human Rights and Chinese Values (1995) and International Intervention: From Power Politics to Global Responsibility (2004), as well as numerous articles on human rights and development in leading academic journals in law and political science. Professor Davis, as a public intellectual, has contributed to the debate over constitutional reform and human rights in Hong Kong for over two decades.

Tags: China, indigenous, Indigenous Self-Determination, selfdetermination, Tibet 